\title{
Sustainable food crop production in karst area of Parigi, Pangandaran, West Java: preliminary study
}

\section{Reginawanti Hindersah $^{1 *}$; Nia Kurniati²; Dadang Epi Sukarsa ${ }^{2}$; Rustam $^{3}$; Sondi Kuswaryan ${ }^{4}$}

1) Faculty of Agriculture, Universitas Padjadjaran, Indonesia

2) Faculty of Law Universitas Padjadjaran, Indonesia

3) National Geological Agency, Ministry of Energy and Mineral Resources, Indonesia

4) Faculty of Animal Husbandry, Universitas Padjadjaran, Indonesia

*To whom correspondence should be addressed.Email: reginawanti@unpad.ac.id

\begin{tabular}{|l|l|l|l|l|}
\hline DOI: & Received: & Revised: & Accepted: & Published: \\
10.22437/ppd.v8i1.7599 & 04.09 .2019 & 09.03 .2020 & 13.03 .2020 & 30.04 .2020 \\
\hline
\end{tabular}

\begin{abstract}
Karst formations in Selasari and Parakanmanggu Village of Parigi District, Pangandaran Regency, West Java includes dolines, subterranean stream, springs, and karst hills are useful for agriculture. The purpose of this study was to 1) identifiy the used of karst area for rice cultivation and local trees in karst area; 2) evaluate the benefit of rice cultivation and local tree for local communities and 3) asses the legal aspect for supporting food crop production. The study was done using qualitative-descriptive method with the primary data obtained from field observations, soil analysis, local tree identification, and interviews. Secondary data was obtained from the Regional Government and the National Geological Agency. The results showed that rice cultivation has been carried out in suitable soil by using simple and rainfed irrigation. Local fruit, herbs, timber and shade-ornamental tree grow naturally on the karst area. Tree logging without significant revegetation caused water supply shortage so that farmers only grow rice once a year. Athough the rice productivity of both villages is lower than average rice productivity of Pangandaran Regency, rice is important to support local inhabitant's consumption and family income. Land Use Plan year 2018 regulates the general provisions on zoning regulations for agriculture in susceptible area but the regulation does not mention the karst areas. This study suggested that tree conservation is needed to maintain the existence of rice fields. Land use planning for agriculture in the region must be based on integrated considerations of rice cultivation and local tree conservation.
\end{abstract}

Keywords: Karst region, Land conservation, Local tree, Rice.

JEL Classification: Q15, Q23

\section{INTRODUCTION}

Karst is a type of landscape in the form of a basin or small hill which is formed through erosion and dissolution of limestone and dolomite (Hartmann, Goldscheider, Wagener, Lange, \& Weiler, 2014). Karst area is a medium for water infiltration into the ground and creating groundwater and springs. On the surface, carbonate stones go 
through dissolution process by rainwater and thus forming karst landscape which is characterized by hill, doline, cave and river (Radulovic, 2013).

Karst surface erosion causes the main rocks (regolith) to be exposed by the atmosphere and later form the soil (Klimchouk, 2014). Regolith weathering is important initial stage of soil formation; and integral part of agriculture in the karst area. The process of soil formation is slow and susceptible to erosion mainly in sloping area where rainwater easily moves the soil to the lower part. Eroded soil from the sloping area settles in the karst foothills and karst valleys (doline) where agriculture taken place. Soil in karst areas is generally high in calcium and low in fertility (Yang, Liang, Chen \& Cao, 2015) but suitable for local food production.

Parigi district in Pangandaran Regency of West Java has karst landscape include hill and doline that intensively used for agriculture by communities. In most part of Pangandaran, agriculture is still important economic activity. Agriculture in the broad sense contributed to at least $26 \%$ of Pangandaran revenue; especially from rice, coconut, livestock and fisheries (Pangandaran dalam Angka, 2017).

Agricultural area in Pangandaran Regency is approximately 15,125 ha which is written in article 47 paragraph (2) of Pangandaran Regency Regulation No. 3 year 2018 about Pangandaran Regency Spatial Plans of 2018 - 2038. Allocation of land for agriculture in Parigi District area were 2,095 ha of rice field and 8,687.57 ha of dry land. Rice field consists of simple-irrigated and rainfed field which cover the area of 1,421 ha and 714 ha respectively. Parigi has 906 ha of State forest, 981.21 ha of community forest and 4,493.63 ha of community estate (Parigi dalam Angka, 2018: 31) which plays an important role in protecting land and water for agriculture, mainly lowland rice field.

Rice cultivation in the karst area of Parigi is important for food security as well as community income. Water is an important part in agriculture; the existence of ground water, subterranean stream, surface water and springs as a source of water for agriculture in karst areas (Baker and Groves, 2008). The watercourse is depends on karst hydrological functions that can be optimized, among others, by maintaining the presence of vegetation on karst. The karst formation process will create unique microclimates and habitats (Efe, 2014) that support indigenous plants and tree. On the other hand, without appropriate protection, vegetation in karst is vulnerable to damage by excessive anthropogenic activities. Protection of tree in karst hills is needed to strengthen the role of karst on water supply for rice field in the downhills. Hence, land use planning in the region should be based on an integrated consideration of both systems (rice cultivation and local tree) rather than considering the two systems independently (Nautiyal, Maikhuri, Semwal, Rao, \& Saxena,-1998).

The geological aspects of karst in the Parigi District have been identified by the National Geological Agency in 2017 and 2018, but the existence of agriculture and vegetation in karst ecosystems of Parigi has never been studied. The objective of this research was to 1) identifiy the used of karst area for rice cultivation and local trees in karst area; 2) evaluate the benefit of rice cultivation and local tree for the communities living in studied area and 3) asses the legal aspect for supporting food crop production.

\section{METHODS}

The study was accomplished from July 2018 to September 2018 in Selasari Village and Parakanmanggu Village which located in Parigi District, Pangandaran Regency, West Java (Fig. 1). Both locations are located in the western part of Pangandaran where geological aspects of the karst have been reviewed by the National 
Geological Agency in 2017. A humid tropical climate characterizes the area. The mean maximum and minimum monthly temperature at July and August 2018 was $28.7^{\circ} \mathrm{C}$ and $22.7^{\circ} \mathrm{C}$ repectively. In general, Pangandaran Regency has dry season (east season) and rainy season (west season) with annual temperature between $20^{\circ} \mathrm{C}-30^{\circ} \mathrm{C}$, rainfall of $1.647 \mathrm{~mm}$, and humidity between $85 \%-89 \%$.

The research was carried out by used of descriptive qualitative method based on primary and secondary data. The description of karst land use was collected by field observations, interview and Focus Group Dscussion (Astalin, 2013) that involve the communities living in study area. Rice production system was directly observed in field supported by primary and secondary data on soil characteristics. Soil organic carbon and acidity was measured from soil sample by using standard method for soil analysis (Eviati and Sulaeman, 2009); soil samples were taken by composite method.

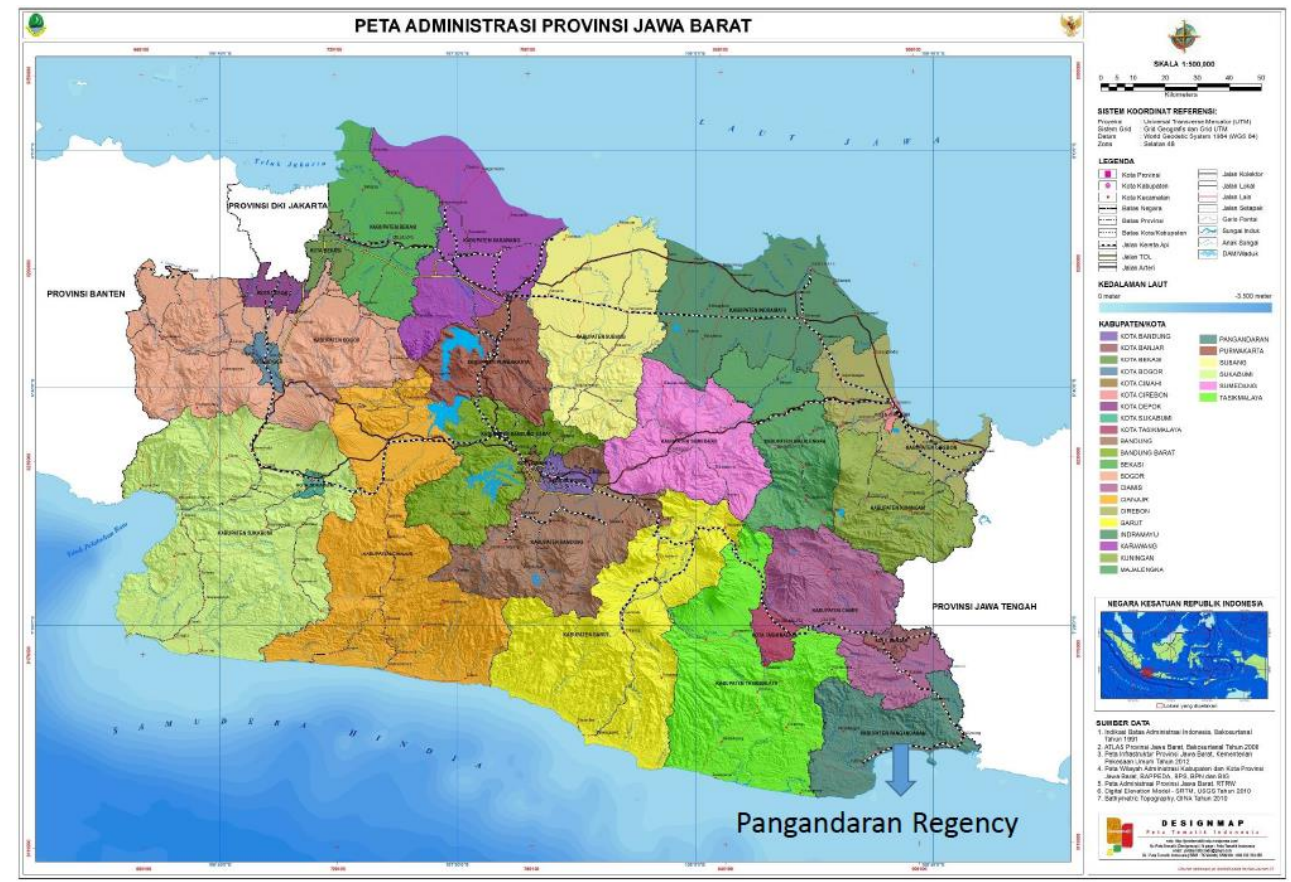

Figure 1. Pangandaran Regency is located at the southern and eastern ends of West Java Province

Purposive sampling based on non-random and subjective consideration; and convenience sampling which select the samples according to our wishes were chosen to establish a sample of karst area, as well as rice field and tree area to be studied. Secondary data were obtained from the Development Planning Agency and the Agriculture Office of Pangandaran Regency; and the National Geological Agency in Bandung, West Java. Local perennial tree exploration was carried out by identifying local trees on karst hills and grouping them according to their use by residents. Local names of trees were obtained through interviews and scientific names were determined based on binomial nomenclature.

\section{RESULTS AND DISCUSSION}

Parigi District has some geological features include dolines, subterranean stream, springs, and karst hills (Gunawan, Afrian, \& Supratman, 2017) to support rice cultivation. Spring and subterranean watercourses way that come up to the surface (Fig 2) play an important role to irrigate rice field in the ridge of karst hill and doline. 

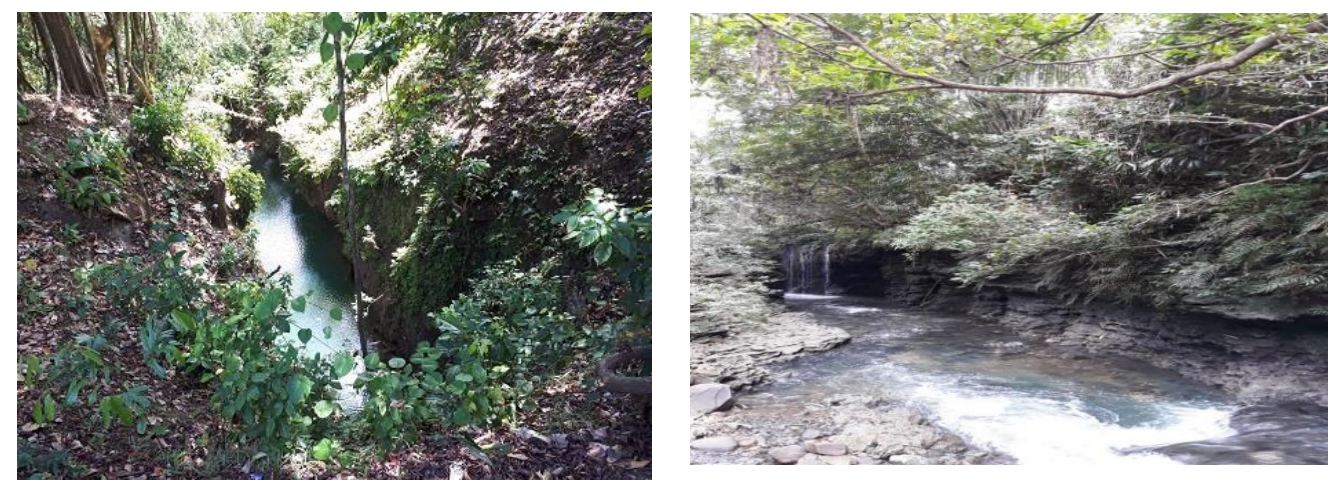

Figure 2. Watercourses way in Karst area at Parakanmanggu Village (left) and Selasari Village (right) in Parigi District

\section{Rice Cultivation in Doline of Karst Area}

Rice fields was main agriculture in doline (Fig 3); a closed basin where eroded soil accumulated (Radulovic, 2013) forming a thick solum on its surface. The soil thickness in rice fields are up to $50 \mathrm{~cm}$; enabling the cultivation of lowland rice that only requires a maximum depth of plow layer of $40 \mathrm{~cm}$ (Wahab, Abdulrachman, Suprihanto, \& Guswara, 2017).

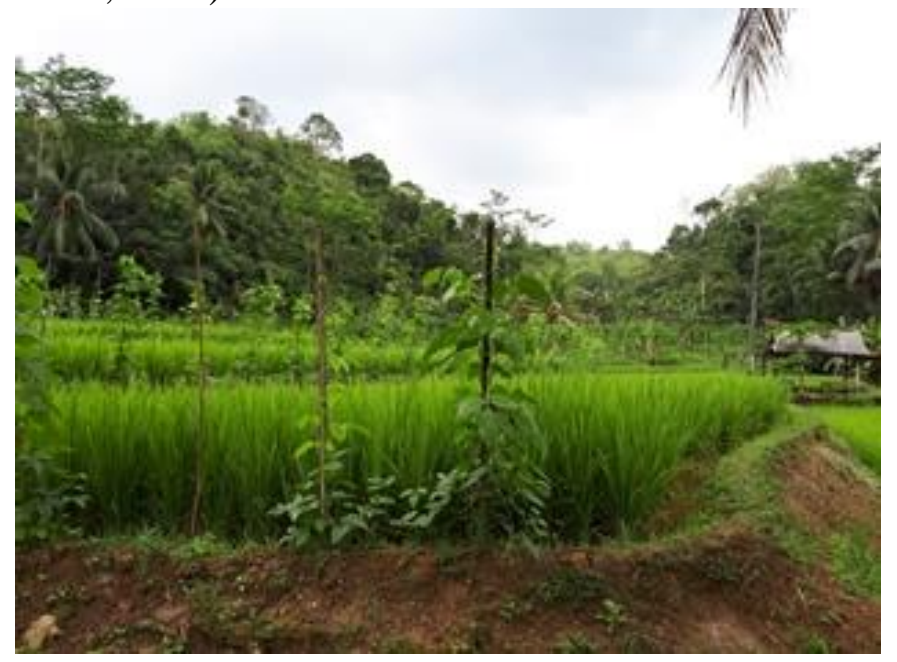

Figure 3. Rice field and vegetable in the dike irrigated by watercourse way from karst hill around the field.

Most of lowland rice field in both villages received water from simple irrigation system made by the communities and rainfed irrigation. Before transplanting, soil is plowing by mixing with roots of previous paddy and then harrowing with traditional methods; farmers do not use tractor in soil preparation. Paddy farmers carry out conservation farming techniques by forming terraces in steep land; and they prefer to cultivate the rice in the flat area of doline instead of steep area. Rice is never grown on the ridge of karst hill due to shallow soil and rock will inhibit root growth.

Soil contained soil organic matter as much as $2.4 \%$ equal to $1,39 \%$ of organic carbon so that the soil particles are stable, support the development of soil microbes, the availability of plant nutrients, and provide optimal growing media for roots (Bot and Benites, 2005). Neutral acidity of 6.8 ensure the availability of macronutrient nitrogen, phosphate and potassium; as well as prevents excessive uptake of ferrous ions and other (heavy) metal (Hartatik, Sulaeman \& Kasno, 2005; Oseni Olalekan, Taiwo Abayomi, 
Ijaola Taiwo, \& Yenusa Luqman 2016). The method of rice cultivation in study area is in line with the principles of Integrated Crop Management for irrigated lowland rice through the adoption of technology which adjust with local conditions to preserve the nature (Abdulrachman, Mejaya, Sasmita, \& Guswara, 2013).

Rice production in Pangandaran at 2016 was 189,990 tons in which 98,68\% was lowland rice but no rice production data of 2017 as well as 2018 (Pangandaran dalam Angka, 2019). The harvested area of lowland rice Pangandaran Regency was 31,131 ha while in Parigi was 9,928 ha in 2016 (Pangandaran dalam Angka, 2019). Parigi Subdistrict didn't have accurate data of both Selasari and Parakanmanggu rice production. The area of paddy fields in both village is 359 ha. According to personal communication with Agricultural Extention Worker, the average productivity of lowland rice in both villages are only 4 tons/ha lower than that of Pangandaran, 6-8 t/ha. However, both villages contributed 1,436 tons of rice to Pangandaran's rice production. Currently rice production in both villages increased and reach up to 2,154 t per year. Although local government has no accurate data, it is clear that rice in the karst area contributes to the availability of rice in Parigi and Pangandaran.

Farmers in Selasari and Parakanmanggu grow introduced rice recommended by the government, namely Ciherang, IR64 cultivars and currently Inpari 43. However, inhabitant and farmers think that the taste of rice grown in Selasari and Parakanmanggu is better than rice in the market so that they never buy rice. Significant contribution of rice to their daily consumption and income is showed; farmers also sell their surplus rice for additional income. Rice cultivation is local wisdom and very important for food safety; the villages had the silo where the inhabitants store the rice as a reserve when rice cultivation is limited due to water supply shortage.

Rice cultivation patterns in the Parigi karst area carried out by farmers and community is along with the agricultural development model in the karst area proposed by Linhua (1999). The cultivation of economic food crops taken place in moderately deep soil and growing annual crops on the top and ridge of karst hill. However, conservation on karst hills, such as simple terraces and individual terraces has not been done in Parigi except for rice fields (Fig. 3). Terraces in karst areas can reduce erosion, as well as increase water infiltration and soil thickness for plant growth (Linhua, 1999; Urich, 2002).

According to local farmers, ten years ago they can cultivate rice twice or three times a year by irrigating the paddy field with water in the creek and springs even in dry season. Nowaday rice production is really depend on rain water. Due to drought under karst ecological conditions in both village, the yield of rice is low. Although in Indonesia 2.5 million ha of rainfed lowland paddy is the second contributor to rice production after irrigated rice, maintaining the sustainability of rice cultivation under existing karst conditions in both villages is not guaranteed without special efforts. Deforestation and illegal logging by local inhabitants in the karst hill cause serious problem in water availability for paddy field. It is inevitable that now and in the future, planting rice in Selasari and Parakanmanggu needs to lift water from underground waterways.

\section{Local Tree Biodiversity}

Karst Hill in both village is believed covered with perrenial indigenous trees which used as timber. Intensive logging in the past resulting the devegetation of karst hill. The communities carried out revegetation program by planting sengon tree (Paraserianthes falcataria (L.) Niels.) and taro (Colocasia esculenta L.) between trees but still leaves open spaces that might induce soil erosion (Fig. 3). 
At least 34 local trees grow on karst hill between the rocks and in doline (Table 1). Different indigenus trees grow scattered on karst hills. Tree biodiversity in studied are can be categorized into a group of fruit, wood, herbs, and shade-ornamental trees. The type of tree that can adapt in karst depends on the topography (Guo et al, 2017), soil formation (Atalay, 1991) and the physical and chemical properties of limestone (Efe, 2014).

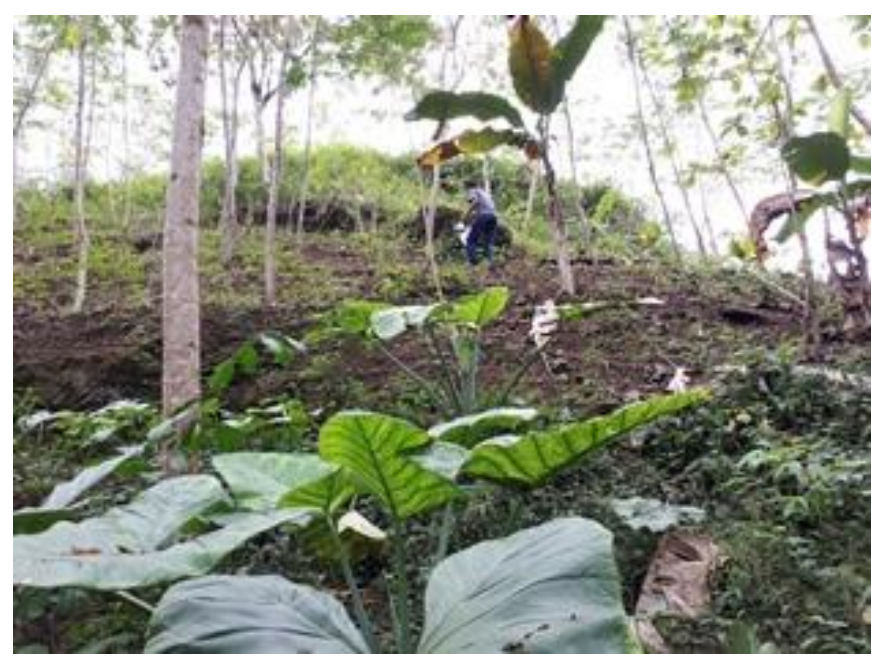

Figure 3. Taro is cultivated by purpose in the ridge of karst hill where the community grows sengon as cash crops

The communities use the trees mainly for food and construction materilas, as well as shade plants. The important plants are Arengga pinnata (Wurmb) Merill (Indonesian: Aren; Sundanese: Kawung) and coconut. Starch is extracted from the stem of aren while coconut fruits are purchased; both of comodities are traditional cash crops. Woody plants such as Wangkal, Kiara, Suren, Ki Teja and Ki Rinyuh are utilized as medium quality wood for home onstruction. Albizia and Kiara (bamboo) are good quality wood that they sell when cash is needed. Bamboo is multipurpose construction material and became a part of the family economy; bamboo is also socially important. The communities used bamboo to build the house, non-permanent buildings and bagan (fishing platform; liftnet) for catching the fish in the ocean; as well as to make stalks for climbing food crops.

Local fruit trees (Kokosan, Nangka and Pisitan) do not provide economic benefits but they are source of vitamins and minerals for the inhabitants. Important economical local legumes trees are Jengkol and Petai since they are a part of local culinary in West Java; while most of the surplus beans was stored, surplus Jengkol and Petai were sold for cash.

Trees are grown in community forest although a part of forest belong to a person or family without certificate of ownership. That natural resources are a social capital correlated to trust, social norms, and social networks developed in the community (Roslinda, Ekyastuti, \& Kartikawati, 2017). Local tree in both villages provide a means by which inhabitants can take part in conserve the tree and obtain benefits. The interrelation among forests (trees), agricultural systems and role of people are recognised as key to climate change adaptation. Limited access to tree logging is a way to imply better forest tree preservation to ensure sustainable exploitation of tree products (Matsvange, Sagonda, \& Kaundikiza, 2016). In the case of Selasari and Parakanmanggu vilages, ensuring tree growing is a way to sustain the water availability for rice cultivation. 
Table 1. Indigenous tree grown naturally on the top of karst hill in Batu Lumpang garden, Tawangmangu Village, Parigi District

\begin{tabular}{|c|c|c|c|}
\hline Local Name & Binomial name & Local Name & Binomial Name \\
\hline \multicolumn{2}{|r|}{ Fruits Tree } & \multicolumn{2}{|c|}{ Shade and Ornamental Tree } \\
\hline Kokosan & $\begin{array}{l}\text { Lansium domesticum (Corr) } \\
\text { cv. Kokosan }\end{array}$ & Heras/Laban & Vitex pinnata $\mathrm{L}$. \\
\hline Nangka & $\begin{array}{l}\text { Artocarpus heterophyllus } \\
\text { Lam. }\end{array}$ & Huru & Litsea sp. \\
\hline Pisitan & $\begin{array}{l}\text { Lansium parasiticum } \\
\text { (Osbeck) Sahni \& Bennet }\end{array}$ & Kanyere & Vitex trofolia $\mathrm{L}$. \\
\hline Kelapa & Cocos nucifera (L) & \multirow{3}{*}{$\begin{array}{l}\text { Ki Ciyat } \\
\text { Ki Rinyuh }\end{array}$} & \multirow{3}{*}{$\begin{array}{l}\text { Ficus fistulosa } \mathrm{L} \text {. } \\
\text { Eupatorium inulifolium } \\
\text { Kunth. }\end{array}$} \\
\hline \multicolumn{2}{|r|}{ Herbs Tree } & & \\
\hline Jengkol & $\begin{array}{l}\text { Archidendron pauciflorum } \\
\text { (Benth.) I.C. Nielsen }\end{array}$ & & \\
\hline Kawung & $\begin{array}{l}\text { Arengga pinnata (Wurmb) } \\
\text { Merill. }\end{array}$ & Ki Teja & $\begin{array}{l}\text { Daphiniphylum } \\
\text { glaucescens Blume. }\end{array}$ \\
\hline Picung & Pangium edule Reinw. & Kiara Tapak & Ficus sp. \\
\hline Salam & $\begin{array}{l}\text { Syzygium polyanthum } \\
\text { (Wight) Walp. }\end{array}$ & Kondang & Ficus variegata Blume. \\
\hline \multicolumn{2}{|r|}{ Wood Tree } & Kopeng & $\begin{array}{l}\text { Filicium decipiens (Wight } \\
\text { \& Arn.) }\end{array}$ \\
\hline $\begin{array}{l}\text { Bambu Awi } \\
\text { (Haur) }\end{array}$ & Phyllostachys sp. & Kopo & $\begin{array}{l}\text { Syzygium densiflorum } \\
\text { Wall. ex Wight \& Arn }\end{array}$ \\
\hline Bambu Kiara & Fargesia sp. & Loa or Ara & Ficus racemosa L. \\
\hline Suren & Toona Sureni (Blume) Merr. & Mara & $\begin{array}{l}\text { Macaranga tanarius (L.) } \\
\text { Müll.Arg. }\end{array}$ \\
\hline \multirow{2}{*}{\multicolumn{2}{|c|}{ Shade and Ornamental Tree }} & Nangsi & $\begin{array}{l}\text { Villebrunea rubescens } \\
\text { (B1.) }\end{array}$ \\
\hline & & Pangsor & Ficus callosa Willd. \\
\hline Albasia & Albizia Falcata (L) & Pongporang & Oroxylum indicum (L.) \\
\hline Bungur & Lagerstroemia speciosa $\mathrm{L}$. & & Vent \\
\hline Cayur & $\begin{array}{l}\text { Pterospermum javanicum } \\
\text { Jungh. }\end{array}$ & Sulangkar & Leea sambucina $(\mathrm{L})$ Willd \\
\hline Hantap & $\begin{array}{l}\text { Pterocymbium tinctorium } \\
\text { Merrill. }\end{array}$ & Wangkal & Albizia procera (Roxb) \\
\hline Hampelas & Ficus ampelas Burm. f & Waringin & Ficus benjamina L. \\
\hline
\end{tabular}

These trees In particular area, rocks have been exposed between the trees showing the removal of vegetation in the past (Fig 4). Vegetation on karst plays an important role in the karst ecosystem because it reduces surface water and guarantees a balance of water infiltrate into the karst system (Liu et al., 2013). Excessive exploitation (logging) of timber tree at certain karst hill has led to deforestation and limited water reserves for rice cultivation.

The sustainability of food crop production in the karst area is not only determined by environmental and cultivation factors, but also depend on regulations and policies of the land use for agriculture in karst landscape. Actually, "Agricultural Area" has been determine by Regional Regulation of Land Use Plan year 2018. The Pangandaran Government has already allocated a total of 20,122 ha of land as the "Sustainable Food Crops Agricultural Zone" in accordance with Law No.41 of 2009 concerning Protection of Sustainable Food Crops Agricultural Land. The purpose of said regulation is 
protecting the area and land for food crops agriculture and assuring the availability of sustainable agriculture. Nowadays Pangandaran Regency has not yet Regency Spatial Detail Plan and their zoning regulations. Once the Spatial Detail Plan is put out, the regulation of sustainable agricultural land for food crops should be complied with the plan.

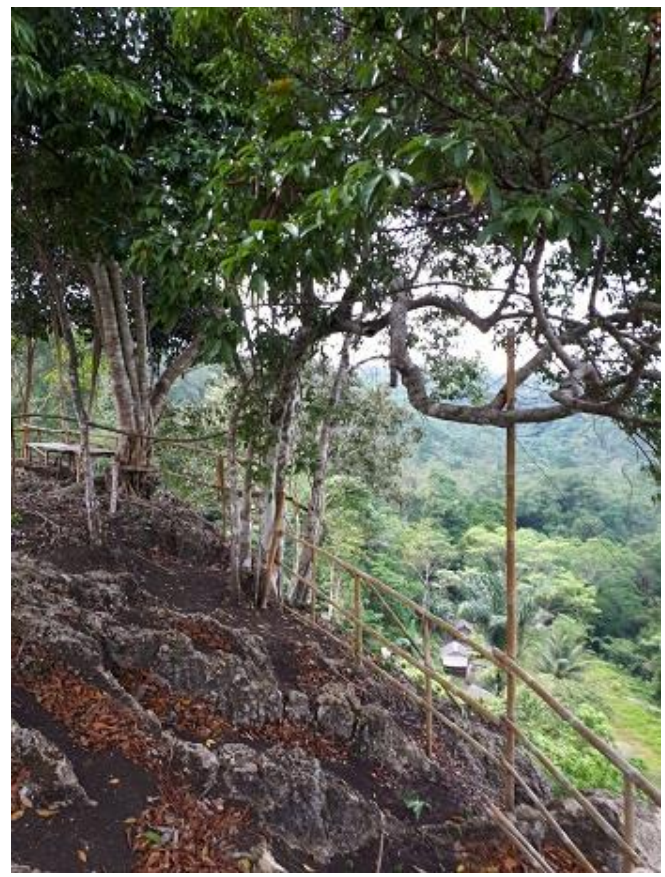

Figure 4. Local tree grown naturally in the top of karst hill in Batulumpang Garden where devegetation leaving the bare rocks

Land Use Plan year 2018 also regulates the general provisions on zoning regulations for agriculture in area susceptible to landslide, earthquake, mudslide, or sinking of the earth. Although the regulation does not implicitly mention the karst areas, these general rules remain comply with vulnerable karst areas. Implementation of Karst Landscape Area in Pangandaran will assure the production of rice and other food crops are carried out on the save and legal area. Protected Karst Landscape Area, include their vegetation and hydrology, is important for sustinable food crops production which is in turn enhance communities heath and revenue.

\section{CONCLUSIONS AND RECCOMENDATION}

\section{Conclusions}

Rice cultivation method in both villages are in line with the principles of Integrated Crop Management for lowland rice through the adoption of technology which adjust with local conditions to preserve the nature. Karst area provide land and water for rice cultivation in studied are that contribute to rice production of Parigi District as well as Pangandaran Regency. Athough the rice productivity of both villages is lower than average rice productivity of Pangandaran Regency, rice is important to support local inhabitants consumption and family inocme.

A total of 34 local trees include fruit, herbal, wood and shade-ornamental groups were found in the karst of the studied area. Trees benefit the communities by improving air quality, providing shade, increasing family income and providing water for rice cultivation. Lack of irrigation water due to tree logging by inhabitants cause the change in rice planting season. Currently the farmer only grow rice once a year. This situation 
threaten the family income, food safety, and sustainable rice production it self. Despite of usefulness of tree in karst area, vegetation conservation and revegetation with local tree has not yet been done.

\section{Recommendations}

This research suggested that local trees need to be studied more as a part of forest or garden conservation which is including establishment local trees nursery to support revegetation with plant adaptive to harsh local conditions. Moreover, the local government should develop permanent irrigation system by taking advantege of underground waterways and spring water. Otherwise the availability of water sources is depend on the tree growing in upper zone of karst area. Sustainable food crop production in the karst area actually has been regulated by some general regulation but land use planning for agriculture in the region should be based on an integrated consideration of rice cultivation and local tree conservation.

\section{ACKNOWLEDGMENT}

We thank the Head of Regional Planning and Development Agency as well as Regional office of Agrarian Affairs and Spatial Planning/National Land Agency in Pangandaran. This research was funded by Universitas Padjadjaran Lecturer Competence Research scheme year 2018.

\section{REFERENCES}

Astalin, P.K., (2013). Qualitative research designs: a conceptual framework. International, Journal of Social Science \& Interdisciplinary Research, 2(1), 118124.

Atalay, I., (1991). Soil forming in the karstic terrains of Turkey. Bulletin of Geomorphology, 19, 139-144.

Abdulrachman, A., Mejaya, M.J., Sasmita, P., \& Guswara, A., (2013). Pengelolaan Tanaman Terpadu Padi Sawah Irigasi. Sukamandi: Balai Besar Penelitian Tanaman Padi Badan Penelitian dan Pengembangan Pertanian Kementerian Pertanian.

Baker, T.W., \& Groves, C.G., (2008). Water Quality Impacts from Agricultural Land Use in Karst Drainage Basins of SW Kentucky and SW China. Proceeding of The Third Interagency Conference on Research in the Watersheds, 8-11 September 2008, Estes Park, CO. pp 103-116.

Bot, A., \& Benites, J., (2005). The importance of Soil Organic Matter: Key to DroughtResistant Soil and Sustained Food and Production. Rome: Food and Agriculture Organization of the United Nations.

Eviati, \& Sulaeman, (2009). Analisis Kimia Tanah, Tanaman, Air, dan Pupuk: Petunjuk Teknis. Bogor: Balai Penelitian Tanah.

Efe, R., (2014). Ecological properties of vegetation formation on karst terrains in the Central Taurus Mauntains (Southern Turkey). Procedia - Social and Behavioral Sciences, 120(2014) $673-679$.

Guo, Y., Wang, B., Mallik, A.U., Huang, F.U., Xiang, W., Ding, T., Wen, S., Lu, S., Li, D., He, Y., \& Li, X., (2017). Topographic species-habitat associations of tree species in a heterogeneous tropical karst seasonal rain forest, China. Journal of Plant Ecology, 10(3), 450-460.

Hartatik, W., Sulaeman, \& Kasno, A., (2006). Perubahan Sifat Kimia Tanah dan Ameliorasi Sawah Bukaan Baru. In Fakhuddin, A (Ed). Lahan Sawah Bukaan Baru (pp 53-75). Bogor: Balai Penelitian Tanah, Badan Penelitian dan 
Pengembangan Pertanian, Kementrian Pertanian.

Hartmann, A., Goldscheider, N., Wagener, T., Lange, J., \& Weiler, M., (2014). Karst water resources in a changing world: review of hydrological modeling approaches. Reviews of Geophysics, 52(3), 218-242.

Klimchouk, A., (2004). Towards defining, delimiting and classifying epikarst: Its origin, processes and variants of geomorphic evolution. Speleogenesis and Evolution of Karst Aquifers, 2(1), 1-13.

Linhua, S., (1999). Sustainable development of agriculture in karst areas, South China. International Journal of. Speleology, 28B (1/4), 139-148.

Liu, Y., Liu, C., Wang, S., Guo, K., Yang, J., Zhang, X., \& Li, G., (2013). Organic carbon storage in four ecosystem types in the karst region of southwestern China. PLoS ONE, 8(2), e56443.

Matsvange, D., Sagonda, R., \& Kaundikiza, M., (2016). The role of communities in sustainable land and forest management: the case of Nyanga, Zvimba and Guruve districts of Zimbabwe. Jamba, 8(3), 281.

Nautiyal, S., Maikhuri, R.K., Semwal, R.L., Rao, K.S. \& Saxena, K.G., (1998). Agroforestry systems in the rural landscape - a case study in Garhwal Himalaya, India. Agroforestry Systems, 41, 151-165.

Oseni Olalekan, A., Taiwo Abayomi, G., Ijaola Taiwo, O., \& Yenusa Luqman, A., (2016). The effects of $\mathrm{pH}$ on the levels of some heavy metals in soil samples of five dumpsites in abeokuta and its environs. International Journal of Science and Research, 5(9), 1543-1545.

Radulović, M.M., (2013). A new view on karst genesis. Carbonates and Evaporites, 28(4), 383-397.

Roslinda, E., Ekyastuti, W., \& Kartikawati, S.M., (2017). Social capital of community forest management on Nusapati Village, Mempawah District, West Kalimantan, Indonesia. Biodiversitas. 18(2), 548-554.

Rustam, Gunawan, G.G., Afrian, R., \& Supratman, H., (2017). Penyusunan Peta Kawasan Bentang Alam Karst Kabupaten Pangandaran Bagian Barat Provinsi Jawa Barat. Report No.03/LAP- BGE.P2K/2017. Bandung: Program Penelitian, Mitigasi dan Pelayanan Geologi. Pusat tata air dan Geologi tata Lingkungan, Badan Geologi, Kementrian ESDM.

Urich, P.B., (2002). Land Use in Karst Terrain: Review of Impacts of Primary Activities on Temperate Karst Ecosystems. Science for Conservation 198. Department of Conservation, Wellington.

Wahab, M.I., Abdulrachman, S., Suprihanto, S., \& Guswara, A., (2017). Daftar Periksa Budidaya Padi Sawah Lahan Irigasi. Sukamandi: Balai Besar Penelitian Tanaman Padi Badan Penelitian dan Pengembangan Pertanian Kementerian Pertanian,

Yang, H., Liang, J., Chen, J., \& Cao, J., (2015). Soil calcium speciation at different geomorphological positions in the Yaji Karst Experimental Site in Guilin. Journal of Resources and Ecology, 6(4), 224-229.

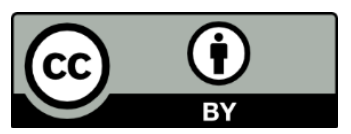

(C) 2020 by the authors. Licensee JPPD, Indonesia. This article is an open access article distributed under the terms and conditions of the Creative Commons Attribution (CC BY) license (http://creativecommons.org/licenses/by/4.0/). 